Original article

\title{
Study of the properties of thirteen tropical wood species to improve the prediction of cutting forces in mode $B$.
}

\author{
Florent EYMA ${ }^{\mathrm{a} *}$, Pierre-Jean MÉAUSOONE $^{\mathrm{b}}$, Patrick MARTIN ${ }^{\mathrm{c}}$ \\ ${ }^{a}$ IUT Paul Sabatier, Dépt GMP, University of Toulouse, 1 rue Lautréamont, 65000, Tarbes, France \\ b Enstib, University of Nancy, 27 rue du Merle Blanc, 88000, Épinal, France \\ ${ }^{\mathrm{c}}$ Ensam, 4 rue des Augustin Fresnel, 57000, Metz, France
}

(Received 13 September 2002; accepted 16 December 2002)

\begin{abstract}
The aim of this study is to investigate the influence of the physical and mechanical characteristics on the behaviour of wood during machining (for cutting process 90-0). In order to work on relatively homogeneous wood species, it was decided to use tropical woods. Different characteristics were measured: Physical (specific gravity, shrinkage) and Mechanical (hardness, fracture toughness, shearing, compression parallel to the grain), These characteristics were assessed separately to cutting forces involved during machining. Results obtained showed good correlations, particularly with very good results for fracture toughness parameters. Then, different formulations, based on statistical analysis, using all parameters, allowed to define a new material coefficient $\mathrm{K}_{\mathrm{m}}$ to predict the general behaviour of wood during machining and the cutting forces involved more precisely. It appeared clearly that the study of wood characteristics is a good means to improve knowledge on cutting condition optimisation, and to predict quality and efficiency of the cutting process.
\end{abstract}

cutting forces / mechanical characteristics / tropical wood / specific gravity / wood machining

Résumé - Étude des propriétés de 13 essences de bois tropicaux pour améliorer la prédiction des efforts de coupe en mode B. Le but de ce travail est d'étudier l'effet des caractéristiques physiques et mécaniques du bois sur son comportement durant l'usinage (dans le processus de coupe 90-0). De façon à travailler avec des essences de bois relativement homogènes, il a été décidé d'utiliser des bois tropicaux. Différentes caractéristiques ont été mesurées : physiques (infradensité, retraits) et mécaniques (dureté, ténacité, cisaillement et compression parallèle au fil du bois). Ces caractéristiques furent comparées séparément aux efforts de coupe induits lors de l'usinage. Les résultats obtenus ont montré de bonnes corrélations, avec notamment de très bons résultats pour les paramètres de ténacité. Puis, on a obtenu plusieurs formulations basées sur une analyse statistique, et utilisant l'ensemble des paramètres. Ces formulations, par l'intermédiaire d'un nouveau coefficient de matériau $\mathrm{K}_{\mathrm{m}}$, ont permis de définir plus précisément le comportement général du bois au cours de l'usinage et les efforts de coupe induits. Il apparaît clairement que l'étude des caractéristiques du bois est un bon moyen pour améliorer les connaissances concernant l'optimisation des conditions de coupe, et pour prédire la qualité et l'efficacité du processus de coupe.

efforts de coupe / propriétés mécaniques / bois tropicaux / infradensité / usinage du bois

\section{INTRODUCTION}

This work deals with the study of the routing cutting process $90-0[15,27]$, i.e. peripheral milling parallel to grain (rotating cut), very often met in second processing wood industry. Today, for wood industries, correct control of the cutting process and better knowledge of the interaction between tools and wood have become essential for productive and economical purposes [9]. However, at present, to estimate cutting forces during wood machining, a factor remains difficult to take into consideration: the influence of wood species. Therefore, the aim of this study is to understand the influence of the internal structural characteristics and the behaviour of each species during the machining operation.
Today, to quickly estimate cutting forces involved, most methods just use Specific Gravity and Moisture Content to describe the influence of wood [11]. However, wood anisotropy provides wood species with completely different characteristics. Thus, it is standard to find wood from the same species with completely different specific gravities. It is also well known that sometimes, two species with the same specific gravity need very different cutting forces, or species with completely different specific gravities need similar cutting forces! These considerations show that specific gravity and humidity alone can not fully explain relationships between wood species and cutting forces. That is the reason why the internal structural characteristics of each species must be considered [29].

\footnotetext{
* Corresponding author: florent.eyma@ iut-tarbes.fr
} 
Table I. Presentation of the fourteen wood species studied, their specific gravity $(\mathrm{SG})$ and cutting forces involved during their machining $\left(\mathrm{F}_{\mathrm{c}}\right)$.

\begin{tabular}{|c|c|c|c|}
\hline Wood species studied & Scientific name & SG & $\mathrm{Fc}(\mathrm{N})$ \\
\hline Fromager & Ceiba pentandra Gaertn. & 0.204 & 21.14 \\
\hline Ayous & Triplochiton scleroxylon K.Schum. & 0.315 & 30.52 \\
\hline Virola & Virola spp. & 0.418 & 36.70 \\
\hline Niangon & Tarrietia densiflora Aubrev. & 0.47 & 46.60 \\
\hline Grignon franc & Ocotea rubra Mez. & 0.485 & 28.93 \\
\hline Dodomissinga & Parkia nitida Miq. & 0.499 & 41.65 \\
\hline Frake & Terminalia superba Engl. Et Diels & 0.554 & 34.59 \\
\hline Beech & Fagus sylvatica & 0.573 & 33.19 \\
\hline Bagasse & Bagassa guianensis Aubl. & 0.689 & 36.76 \\
\hline Eucalyptus & Eucalyptus globulus Labill. & 0.705 & 46.31 \\
\hline Moabi & Baillonella toxisperma & 0.714 & 35.09 \\
\hline Wacapou & Vouacapoua americana Aubl. & 0.755 & 34.06 \\
\hline Ipé & Tabebuia sp. & 0.851 & 44.92 \\
\hline Boco & Bocoа prouacensis Aubl. & 1.109 & 55.22 \\
\hline
\end{tabular}

Thus, nowadays, we just use specific gravity to estimate the influence of wood species, and then, calculate cutting forces involved. The aim of this work is to find better parameters, linked to wood internal characteristics to estimate, more precisely, the relation between cutting forces and wood species properties.

\section{MATERIALS AND METHODS}

In a previous study [12] several heterogeneous wood species were compared for their specific gravity (e.g. Scot pine). The results were very difficult to explain. Thus, it was difficult to conclude on the real influence of wood species on cutting forces involved (problem of cohesion between earlywood and latewood, ...). In order to obtain very homogeneous characteristics for each species, it was decided to work on tropical wood species. The choice of these woods was made, with the "CIRAD Forest" in Montpellier (France), on woods presenting a large range of specific gravity and very different mechanical characteristics. Thirteen tropical wood species were used (Tab. I). Moreover, Beech ("Fagus Sylvatica") was added to the list because it is a reference in a lot of studies.

\subsection{Physical characteristics measurement}

Each species studied was physically characterised. In collaboration with the wood quality department of INRA (Nancy, France) a microdensitometric analysis of wood samples [31, 33, 36], and a measurement of specific gravity SG were done:

$\mathrm{SG}=\mathrm{M}_{0} / \mathrm{V}_{\text {sat }}$, i.e. anhydrous mass on saturated volume.

Moreover, a measurement of radial, tangential and volumetric shrinkage was done, as described in the standard NF B 51-006 [1]. For radial and tangential measurements, samples used were $50 \mathrm{~mm} \times$ $50 \mathrm{~mm} \times 10 \mathrm{~mm}$ respectively in radial, tangential and longitudinal directions. For volumetric measurement, samples used were $20 \mathrm{~mm}$ cubes. All the results obtained on the 14 different woods were the average of ten measurements, and are presented in Table II. Moisture content was fixed at $12 \%$ for all tests in order to obtain results close to standard literature values. Finally, each wood sample used, was free of defects.

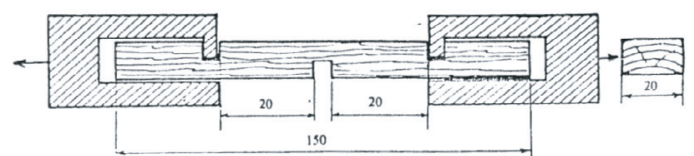

Figure 1. Sample of longitudinal shearing test.

\subsection{Mechanical properties measurement}

The mechanical characteristics studied because involved in the routing cutting process, were chosen from many works found in literature and especially from the studies of Merchant [30] and Franz [15], explaining the influence of mechanical characteristics on the routing cutting process. They wrote the mechanical equilibrium in orthogonal cutting of the force applied on an elementary chip, and tried to predict chip formation, then, cutting forces involved during machining. Considering these formulations, previous mechanical tests [11] and other works $[14,19,22,34,40]$, we have chosen the following mechanical characteristics:

- Shearing parallel to the grain;

- Monnin hardness;

- Compression parallel to the grain;

- Fracture toughness mode I.

\subsubsection{Shearing parallel to the grain measurement}

Shearing test parallel to the grain was done following the standard NF B 51-011 [3]. Sample sizes are $20 \mathrm{~mm}$ (T: Tangential), $10 \mathrm{~mm}$ (R: Radial) and $150 \mathrm{~mm}$ (L: Longitudinal), and are illustrated on Figure 1 . The device used was a universal testing machine INSTRON type 4467 , with a load cell of $30 \mathrm{KN}$ which allowed a precision of \pm 15 N. Different factors were measured (Fig. 2):

- $\boldsymbol{P}$ (N.mm): elasticity (the slope of the curve force/displacement);

- $\boldsymbol{W}_{\boldsymbol{c}}\left(\mathrm{J} / \mathrm{m}^{2}\right)$ : failure energy (the area under the curve before failure); 
Table II. Presentation of results obtained concerning radial, tangential and volumetric shrinkage.

\begin{tabular}{lccc}
\hline Wood species & Volumetric shrinkage coefficient (\%) & Total radial shrinkage (\%) & Total tangential shrinkage $(\%)$ \\
\hline Fromager & 0.19 & 3.65 & 2.53 \\
Ayous & 0.28 & 4.36 & 3.46 \\
Virola & 0.53 & 9.84 & 6.53 \\
Niangon & 0.26 & 6.61 & 3.82 \\
Grignon franc & 0.35 & 7.03 & 3.22 \\
Dodomissinga & 0.36 & 7.36 & 4.33 \\
Frake & 0.30 & 5.19 & 4.31 \\
Beech & 0.46 & 10.13 & 5.60 \\
Bagasse & 0.47 & 4.66 & 3.52 \\
Eucalyptus & 0.48 & 8.99 & 6.10 \\
Moabi & 0.53 & 7.04 & 5.20 \\
Wacapou & 0.49 & 6.41 & 4.51 \\
Ipé & 0.59 & 5.01 & 5.07 \\
Boco & 0.54 & 7.02 & 6.11
\end{tabular}

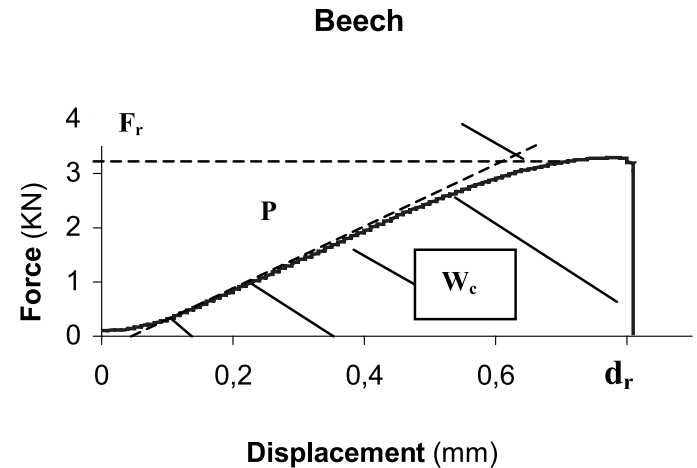

Figure 2. Factors used to describe shearing test.

- $\sigma_{c}$ (Mpa): failure strain.

$$
W_{c}=\frac{1}{S} \times \int_{0}^{d r} F(t) \cdot d t
$$

and

$$
\sigma_{c}=\frac{F_{r}}{S}
$$

where, $\mathrm{S}$ is failure surface $\left(\mathrm{m}^{2}\right) ; \mathrm{F}_{(\mathrm{t})}$ is the force carried on with the displacement " $t$ " $(\mathrm{N})$; dr the failure displacement, and Fr, the force applied to the failure displacement.

\subsubsection{Monnin hardness measurement}

This test followed the standard NF B 51-013 [4]. Samples used are parallelepipeds whose dimensions are $20 \mathrm{~mm}(\mathrm{~T}), 20 \mathrm{~mm}(\mathrm{R})$ and $60 \mathrm{~mm}(\mathrm{~L})$. During these tests, a strength of 200daN exerted progressively with a cylinder of $30 \mathrm{~mm}$ diameter is applied perpendicular to the grain direction for 5 seconds. The mark and the displacement obtained " $t$ " is then, correlated with a value of Monnin hardness " $N$ ". The factor measured " $\mathrm{N}$ " is described as:

$$
N=\frac{1}{t} \text {. }
$$

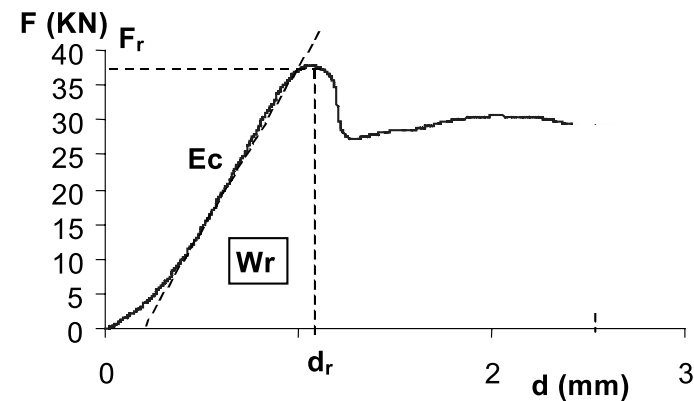

Figure 3. Factors used to describe compression test parallel to the grain direction.

The strength is applied to the tangential-radial sample plane, and the penetration in done on the radial face. The use of a cylinder for this test allowed avoiding irregularities of wood growth rings.

\subsubsection{Compression parallel to the grain measurement}

This test was carried out following standard NF B 51-007 ([2], conform to the international standard ISO 3787). Sample dimensions are the same as those used for hardness: $20 \mathrm{~mm}(\mathrm{~T}), 20 \mathrm{~mm}(\mathrm{R})$ and $60 \mathrm{~mm}$ (L). Different parameters were measured (Fig. 3):

- $\boldsymbol{E}_{\boldsymbol{c}}$ (Mpa): modulus of elasticity;

$$
E_{c}=\frac{\sigma_{r}}{d r}
$$

where $\sigma_{\mathrm{r}}$ is the failure strain (Mpa), and $\mathrm{d}_{\mathrm{r}}$ is the failure displacement

- $\sigma_{r}(\mathrm{Mpa})$ : failure strain;

$$
\sigma_{r}=\frac{F_{r}}{S}
$$

where $\mathrm{F}_{\mathrm{r}}$ is the failure strength $(\mathrm{N})$, and $\mathrm{S}$ the sample section $\left(\mathrm{m}^{2}\right)$.

- $\boldsymbol{W}_{\text {rupt }}\left(\mathrm{J} / \mathrm{m}^{3}\right)$ : energy for failure;

$$
W_{\text {rupt }}=\frac{1}{V} \times \int_{0}^{d r} F(t) \cdot d t
$$




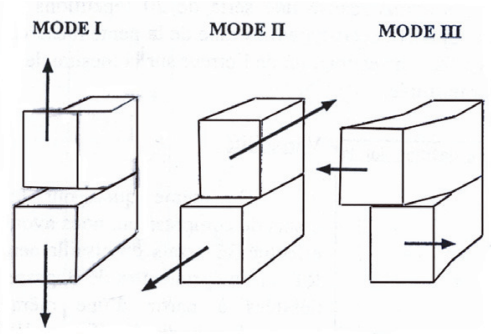

Figure 4. Definition of three cracking modes, in theory of fracture mechanics: open crack (I), longitudinal shear crack (II), and transversal shear crack (III).

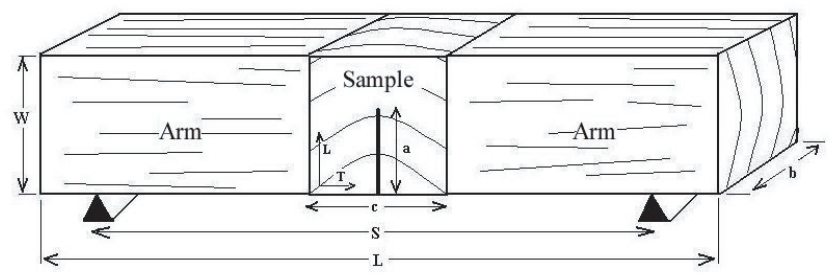

Figure 5. Picture of tenacity sample (dimensions defined by Schatz [31]).

where $\mathrm{V}$ is the sample volume $\left(\mathrm{m}^{3}\right) ; \mathrm{F}(\mathrm{t})$ is the force carried on the displacement " $t$ " $(\mathrm{N})$, and $\mathrm{d}_{\mathrm{t}}$ is the displacement.

\subsubsection{Fracture toughness measurement}

Generally, the crack propagation in the wood cutting process influences either the quality of the chip in veneer cutting, or the quality of the residual surface in other cases. The theory of fracture mechanics $[6,18,25,39,41,42]$ uses three cracking modes to define stress distribution in the chip, and crack propagation (Fig. 4): mode I (i.e. open crack), mode II (i.e. longitudinal shear crack) and mode III (i.e. transversal shear crack).

The test realised here, concerns mode I, and the notch plane is TL (Fig. 5): the first letter is the normal crack plane, and the second letter is the crack propagation direction. The process used is currently subjected to a European standard project [39]. Samples used are SEND type (Single Edge Notched specimen in Bending), and their dimensions are defined by Gustafsson [18] and illustrated on the Figure 5. These samples are composed of three parts:

- Central part: which is the wood sample to be tested;

- Two lateral arms: their role is to allow a perfect test of 3 points bending. The wood species used must present high stiffness and specific gravity. In these tests, a tropical wood was chosen: the Pao Rosa with a specific gravity close to 1 .

These two arms are pasted on the central part with a phenol reorcinol formaldehyde glue. A notch of $21 \mathrm{~mm}$ long and $1.5 \mathrm{~mm}$ large is obtained on the central part with a bandsaw (Fig. 5). On the test machine INSTRON, a load cell of $1 \mathrm{KN}$ was used, and allowed a precision of $\pm 1 \mathrm{~N}$.

Different properties were computed (Fig. 6):

- $\boldsymbol{G}_{\boldsymbol{f}, \boldsymbol{I}}\left(\mathrm{J} / \mathrm{m}^{2}\right)$ : fracture energy;

$$
G_{\mathrm{f}, \mathrm{I}}=\frac{1}{S} \times \int_{0}^{d r}[F(t)+m g] \cdot d t
$$

where $S$ is the failure surface $\left(\mathrm{m}^{2}\right) ; \mathrm{d}_{\mathrm{r}}$ is the failure deflection $(\mathrm{m}) ; \mathrm{F}(\mathrm{t})$ is the force applied to the displacement " $t$ " $(\mathrm{N})$, and $\mathrm{mg}$ is the sample weight $(\mathrm{N})$.

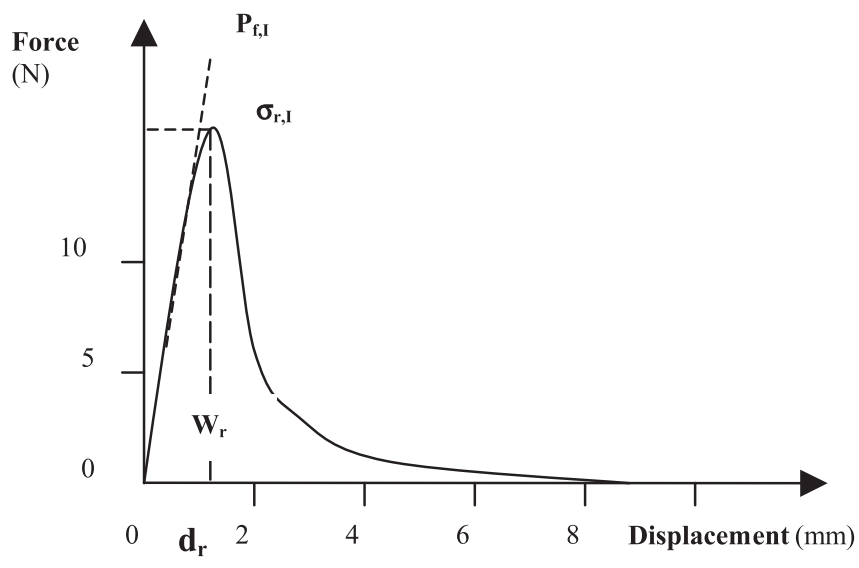

Figure 6. Curve forces - displacement obtained during tenacity tests.
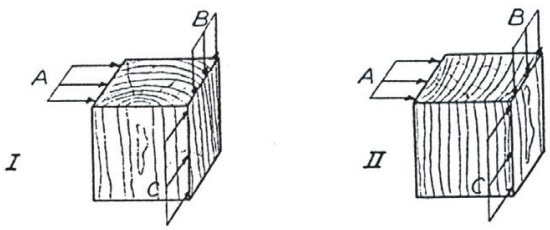

Figure 7. Definition of cutting directions: $\mathrm{A}=$ cutting direction $90-$ 90; $\mathrm{B}=$ cutting direction $90-0$, and $\mathrm{C}=$ cutting direction 0-90.

- $\boldsymbol{P}_{f, I}$ (Mpa): slope of the curve in the elastic part;

$$
P_{\mathrm{f}, \mathrm{I}}=\alpha \times \frac{s^{3}}{4 \times b \times(w-a)^{3}}
$$

where $\mathrm{S}$ is the length between supports (m); $\alpha$ is the slope of the origin tangent; $b$ is the sample width (m), and (w-a) is the breaking segment section $(\mathrm{m})$;

- $\sigma_{r, I}(\mathrm{Mpa})$ : equivalent failure strain;

$$
\sigma_{\mathrm{r}, \mathrm{I}}=\frac{3 \times F_{r} \times S}{2 \times b \times(w-a)^{2}}
$$

where $F_{r}$ is the force applied to the failure $(N)$.

\subsection{Measure of machining parameters}

These tests were run on a CNC router (Computer Numerically Control) in the peripheral milling parallel to the grain cutting process. This machining was done by down-milling, in the cutting direction 90-0-I [28], Figure 7. The dimensions of specimens were: $22 \mathrm{~mm}$ in the tangential direction " $T$ ", $42 \mathrm{~mm}$ in the radial direction " $\mathrm{R}$ " and $135 \mathrm{~mm}$ in the longitudinal direction "L". A groove was made on the side of specimens in order to do the cutting process only with the side of the tool's edge and never with the top. Then, normal and tangential cutting forces were measured with a piezo-electric dynamo-meter attached to the router table (Fig. 8), and allowed the calculation of the resulting cutting force. Each value of total cutting force is an average of 30 values for each wood species.

Machining parameters were fixed in respect to correct utilisation, and optimisation of the router [5]:

- $\mathrm{N}=9000 \mathrm{tr} / \mathrm{min}$ (rotation spindle rate).

- $\mathrm{H}=2 \mathrm{~mm}$ (depth of cut). 


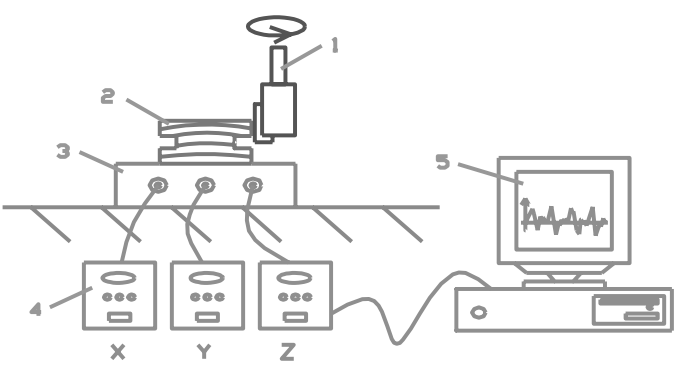

Figure 8. Sketch of router's table with its cutting forces measuring device; where 1 is the cutting tool; 2 is the wood specimen; 3 is piezo-electric sensors; 4 is amplificators, and 5 is the cutting forces system of measurement (Dadisp).

- Vf $=4 \mathrm{~m} / \mathrm{min}$ (feed rate).

- $\mathrm{b}=0.9 \mathrm{~cm}$ (width of cut).

Characteristics of the tool:

- $\varnothing=14 \mathrm{~mm}$ (tool diameter).

- Straight tool: 1 tooth with one tooltip related; rake angle: $23^{\circ}$; clearance angle: $15^{\circ}$.

\section{RESULTS AND DISCUSSIONS}

The aim of this study is to improve the relation that allowed calculating cutting forces involved during machining, and to take into account, more precisely, the influence of wood material in this relationship.

\subsection{Relationship between physical characteristics and cutting forces}

\subsubsection{Relations obtained with specific gravity}

Results of specific gravity and cutting forces obtained are presented in Table I. Concerning the relationship between cutting forces and specific gravity, it was obtained by linear correlation as illustrated on Figure 9. It appears that cutting forces increase with specific gravity. This has been already explained by several authors [20, 22]; a greater specific gravity essentially means fewer cell cavities and more cell walls in the wood. Consequently, the force required to move the tool must also be greater. However, the coefficient of determination obtained in this case $\left(\mathrm{R}^{2}=0.54\right)$ is quite low.

In fact, several authors have worked on the influence of specific gravity: [14, 20, 29] and found a very good linear correlation between specific gravity and force requirements. Nevertheless, for $[7,16,22,38]$, there is a correlation between specific gravity and power requirement (power being directly linked to cutting forces), but this factor is not enough to characterise the influence of wood species precisely. There are always exceptions, and in our case also, there are some ones. For example, Grignon and Niangon present similar specific gravity but required completely different cutting forces $(47 \mathrm{~N}$ compared to $29 \mathrm{~N}$ ).

Then, a study of different wood properties was made.

\subsubsection{Relationship obtained with shrinkage}

Results obtained on the 14 wood species (Tab. II) are very close to information found in the data base of Cirad forest. The
Table III. Results obtained during shearing test parallel to the grain direction, where $\sigma_{\mathrm{c}}$ is the failure strain; $\mathrm{W}_{\mathrm{c}}$ is the energy for failure, and $\mathrm{P}$ is the elasticity parameter.

\begin{tabular}{lccc}
\hline Shearing test & $\sigma_{\mathrm{c}}(\mathrm{Mpa})$ & $\mathrm{W}_{\mathrm{c}}\left(\mathrm{J} / \mathrm{m}^{2}\right)$ & $\mathrm{P}(\mathrm{N} \cdot \mathrm{mm})$ \\
\hline Fromager & 1.30 & 3.970 & 1577 \\
Ayous & 2.48 & 7.730 & 2324 \\
Virola & 4.64 & 11.790 & 4672 \\
Niangon & 5.15 & 16.030 & 4352 \\
Grignon franc & 5.43 & 17.350 & 4554 \\
Dodomissinga & 6.70 & 22.470 & 5226 \\
Frake & 5.96 & 23.070 & 4636 \\
Beech & 7.67 & 34.260 & 5029 \\
Bagasse & 5.64 & 16.800 & 5223 \\
Eucalyptus & 6.20 & 20.730 & 5126 \\
Moabi & 6.48 & 25.650 & 4829 \\
Wacapou & 7.76 & 29.050 & 5889 \\
Ipé & 8.26 & 31.580 & 5765 \\
Boco & 8.78 & 25.290 & 7897 \\
\hline
\end{tabular}

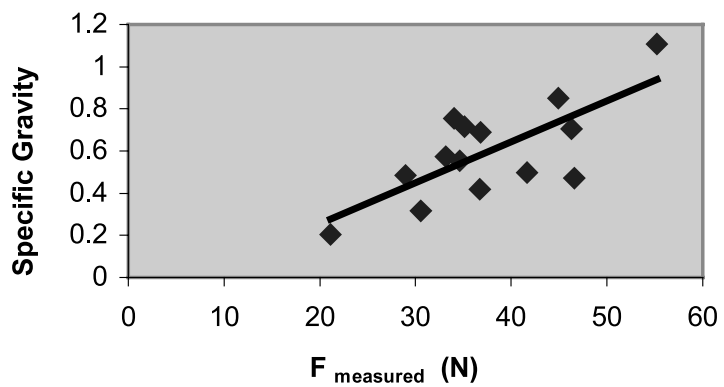

Figure 9. Evolution of cutting forces with specific gravity $(\mathrm{SG}) . \mathrm{F}_{\mathrm{c}}=$ $(27.716 \times \mathrm{SG})+21.036 ; \mathrm{R}^{2}=0.54$.

relationship between shrinkage and cutting forces presents average correlations. The best relationship was obtained for radial shrinkage $\left(\mathrm{R}^{2}=0.37\right)$, and there is no correlation with tangential shrinkage.

\subsection{Relationship between mechanical properties and cutting forces}

\subsubsection{Shearing parallel to the grain}

Results obtained on shearing are presented in Table III. On the three parameters measured, best relations were obtained with the elastic factor " $P$ ", the linear correlation being very close to results obtained with specific gravity:

$$
\begin{gathered}
\mathrm{F}_{\mathrm{c}}=(0.0045 \times \mathrm{P})+16.071 \\
\mathrm{R}^{2}=0.59 ; \boldsymbol{F}_{\boldsymbol{c}} \text { : total cutting force. }
\end{gathered}
$$

The influences of failure strain $\left(\mathrm{R}^{2}=0.44\right)$ and cutting energy $\left(R^{2}=0.18\right)$ on cutting forces are not significant (significance to $1 \%$ : 0.44$)$. Compared to results obtained with specific gravity ( $\mathrm{R}^{2}$ close to 0.54$)$, shearing parameter " $\mathrm{P}$ " seems 


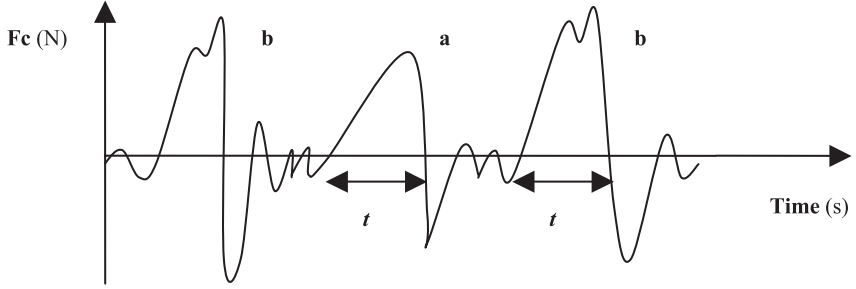

Figure 10. Sketch of results obtained during the cutting forces measurement; where "a" and " $b$ " are different heights of pics, and " $t$ " is machining time.

able to explain the relation between wood species and cutting forces more precisely, and even if the relation is not perfect, this mechanical factor can explain some exceptions that specific gravity does not explain. For example, dodomissinga and frake are wood species with very close specific gravity. However, frake required lower cutting forces, and also present lower shearing characteristics.

Concerning the importance of elastic parameters, several explanations can be given:

- Firstly, from a mechanical point of view: during mechanical tests, the determination of failure strain is done extremely locally, and the lowest mechanical characteristics are obtained; whereas, during wood machining the localisation of cutting forces is extremely accurate and the lowest characteristics are not always measured. Concerning elastic parameters, during mechanical tests, generally an average modulus of elasticity is obtained, very global, that erases local phenomenon, and so, allowed the determination of a better approximation of cutting forces involved during machining.

- The second explanation can be based on the analysis of graphs obtained during wood machining. In fact, cutting forces are measured in a very short period of time $(0.6 \mathrm{~ms})$, and each total cutting force measured is the mean of 6 pics obtained during these $0.6 \mathrm{~ms}$. Then, it is frequent to obtain pics with different heights (Fig. 10). So, it is possible that in some cases (b), the strains involved are very close to wood limit strains (and so, failure strains): case of very high pics. In other cases (a), during the $0.6 \mathrm{~ms}$ of measurement, it is possible that the maximum strains were never met (it is generally the case of woods like dodomissinga: a rool chip is obtained and the maximum strain is never obtained).

\subsubsection{Hardness}

Results obtained for Monnin hardness are presented in Table IV. The relationship between Monnin hardness and cutting forces was expressed by the following linear relationship:

$$
\mathrm{F}_{\mathrm{c}}=(1.0327 \times \mathrm{N})+31.861 \text {. }
$$

This correlation presents an average coefficient of determination $\left(\mathrm{R}^{2}=0.53\right)$. In this case too, as for shearing, even if the relation is not perfect, some exceptions met with specific gravity can be explained with Monnin hardness. Then, moabi whose specific gravity is similar to eucalyptus specific gravity $(\approx 0.71)$, asked for a lower cutting force and also, presented a lower hardness. In fact, during machining, the tool edge rubbed the wood surface permanently, and through friction coefficient
Table IV. Results obtained for Monnin hardness, with the measure of the depth of mark " $t$ " and the determination of Monnin hardness "N".

\begin{tabular}{lcc}
\hline Monnin hardness & Depth of mark $(\mathrm{mm})$ & $\mathrm{N}$ \\
\hline Fromager & 2.928 & 0.34 \\
Ayous & 1.148 & 0.87 \\
Virola & 0.898 & 1.11 \\
Niangon & 0.46 & 2.17 \\
Grignon franc & 0.753 & 1.33 \\
Dodomissinga & 0.38 & 2.63 \\
Frake & 0.198 & 5.05 \\
Beech & 0.242 & 4.13 \\
Bagasse & 0.158 & 6.33 \\
Eucalyptus & 0.134 & 7.46 \\
Moabi & 0.185 & 5.41 \\
Wacapou & 0.143 & 6.99 \\
Ipé & 0.084 & 11.90 \\
Boco & 0.042 & 23.81 \\
\hline
\end{tabular}

Table V. Results obtained during the compression test parallel to the grain direction, where $\sigma_{\text {rupt }}$ is the failure strain; $W_{\text {rupt }}$ is the energy for failure, and $\mathrm{E}_{\mathrm{c}}$ is the elasticity modulus.

\begin{tabular}{lccc}
\hline Compression test & $\sigma_{\text {rupt }}(\mathrm{Mpa})$ & $\mathrm{E}_{\mathrm{c}}(\mathrm{Mpa})$ & $\mathrm{W}_{\text {rupt }}\left(\mathrm{KJ} / \mathrm{m}^{3}\right)$ \\
\hline Fromager & 16.17 & 1373 & 168.8 \\
Ayous & 28.58 & 2292 & 371.6 \\
Virola & 49.10 & 4262 & 335.5 \\
Niangon & 50.61 & 4658 & 345.5 \\
Grignon franc & 48.16 & 4310 & 346.1 \\
Dodomissinga & 54.63 & 5197 & 413.5 \\
Frake & 60.72 & 4906 & 550.8 \\
Beech & 55.44 & 4841 & 599.8 \\
Bagasse & 91.87 & 6951 & 855.6 \\
Eucalyptus & 79.74 & 6408 & 685.4 \\
Moabi & 73.90 & 6103 & 718.9 \\
Wacapou & 84.39 & 6957 & 692.5 \\
Ipé & 97.26 & 6540 & 1553.8 \\
Boco & 148.11 & 9940 & 1362.6 \\
\hline
\end{tabular}

$[21,32,37]$, hardness appeared to be a very important factor to be considered.

\subsubsection{Compression parallel to the grain}

Results obtained in compression are presented in Table V. A good correlation is obtained between cutting forces and the modulus of elasticity in compression:

$$
\mathrm{F}_{\mathrm{c}}=\left(0.0032 \times \mathrm{E}_{\mathrm{c}}\right)+20.554 \text {. }
$$

This correlation is not perfect $\left(\mathrm{R}^{2}=0.60\right)$ but is the best one between compression factors and cutting forces. The other relations with cutting forces were for $\sigma_{\text {rupt }}\left(\mathrm{R}^{2}=0.58\right)$ and for cutting energy $\left(R^{2}=0.41\right)$. In this case too, as for shearing, the 
Table VI. Results obtained for tenacity test, where $\sigma_{r, I}$ is the equivalent failure strain; $G_{f, I}$ is the representation of fracture energy, and $P_{f, I}$ is the elastic parameter.

\begin{tabular}{lccc}
\hline Tenacity test & $\mathrm{G}_{\mathrm{f}, \mathrm{I}}\left(\mathrm{J} / \mathrm{m}^{2}\right)$ & $\sigma_{\mathrm{r}, \mathrm{I}}(\mathrm{Mpa})$ & $\mathrm{P}_{\mathrm{f}, \mathrm{I}}(\mathrm{Mpa})$ \\
\hline Fromager & 27.38 & 1.78 & 403 \\
Ayous & 137.64 & 4.71 & 2254 \\
Virola & 149.27 & 4.09 & 1940 \\
Niangon & 243.76 & 9.89 & 9148 \\
Grignon franc & 175.83 & 5.92 & 3038 \\
Dodomissinga & 216.20 & 8.18 & 4583 \\
Frake & 155.25 & 9.60 & 8664 \\
Beech & 299.75 & 11.35 & 5959 \\
Bagasse & 75.83 & 6.14 & 7244 \\
Eucalyptus & 325.60 & 13.00 & 8245 \\
Moabi & 378.12 & 13.84 & 7552 \\
Wacapou & 132.10 & 8.83 & 8456 \\
Ipé & 212.52 & 13.07 & 14672 \\
Boco & 457.16 & 17.85 & 18080 \\
\hline
\end{tabular}

modulus of elasticity appeared to be the best factor to predict cutting forces involved. It is something very well established in Section 3.3.

As for hardness and shearing, but for different cases, the factor (" $E_{c}$ ") can lead to new information on wood species behaviour.

\subsubsection{Fracture toughness}

Results obtained concerning fracture toughness are presented in Table VI. The best correlation is obtained, in this case too, for the elastic parameter " $\mathrm{P}_{\mathrm{f}, \mathrm{I}}$ ", with the relation:

$$
\begin{gathered}
\mathrm{F}_{\mathrm{c}}=\left(0.0015 \times \mathrm{P}_{\mathrm{f}, \mathrm{I}}\right)+27.15 \\
\mathrm{R}^{2}=0.66 .
\end{gathered}
$$

For the other parameters, relations obtained are relatively good with a coefficient of determination of 0.59 for the equivalent failure strain parameter " $\sigma_{\mathrm{r}, \mathrm{I}}$ ", and 0.49 for the fracture energy parameter " $\mathrm{G}_{\mathrm{f}, \mathrm{I}}$ ". This mechanical test although realised in static, allowed a very good approximation of true wood behaviour during machining. In fact, the unique parameter " $\mathrm{P}_{\mathrm{f}, \mathrm{I}}$ " is able to explain almost $70 \%$ of the variations of cutting forces involved during machining. In comparison with results obtained with specific gravity only, there is an improvement of $15 \%$ of the percentage of variation explained.

This test, although a little more complicated to achieve, allowed an estimation of wood cracking resistance (phenomenon extremely important during machining process [10, 41]). Moreover, it is the best mechanical test used here, to describe cutting forces involved. However, even if this formulation seems correct, it is obvious that some exceptions still don't have explanations. It is, thus, necessary to relativize these results, and some improvement must still be done. Maybe it is possible that the addition of some physical or mechanical characteristics to the specific gravity could increase the accuracy of the relationship between cutting forces and wood species! This is the reason why statistical models were studied as explained Section 3.3.

\subsubsection{Comments about specific gravity}

This study showed that all properties measured presented good correlations with specific gravity (SG), following the model [17, 22-24, 26, 35]:

$$
\mathrm{S}=\mathrm{a} \times \mathrm{SG}^{\mathrm{b}} .
$$

where $S$ represents mechanical characteristics, and SG is the specific gravity.

These correlations are illustrated in the following equations:

$$
\sigma_{\mathrm{c}}=10.33 \times \mathrm{SG}^{1.1}, \mathrm{R}^{2}=0.84
$$

with $\sigma_{\mathrm{c}}$ : failure strain in shearing $(\mathrm{Mpa})$;

$$
\mathrm{N}=15.81 \times \mathrm{SG}^{2.59}, \mathrm{R}^{2}=0.95
$$

with N: Monnin hardness;

$$
\sigma_{\mathrm{r}}=125.59 \times \mathrm{SG}^{1.26}, \mathrm{R}^{2}=0.98
$$

with $\sigma_{\mathrm{r}}$ : failure strain in compression $(\mathrm{Mpa})$;

$$
\mathrm{P}_{\mathrm{f}, \mathrm{I}}=18444 \times \mathrm{SG}^{2.11}, \mathrm{R}^{2}=0.86
$$

with $\mathrm{P}_{\mathrm{f}, \mathrm{I}}$ : equivalent elasticity in fracture toughness (Mpa).

The best correlations were obtained for elastic and failure parameters (with coefficient of determination close to 0.9), and the worst for energy parameters $\left(\mathrm{R}^{2} \approx 0.75\right)$. Correlations obtained are very close to results found in the Cirad forest data base in Montpellier.

\subsection{Study of a statistical model}

Each physical and mechanical characteristic not being able to explain alone cutting forces involved during machining, their combination will probably improve the prediction! Then, it was decided to work on different models.

The methodology used was multiple linear regression, and variance analysis (utilisation of Microsoft software, excel). Some combinations of factors were made with specific gravity, cutting forces, mechanical and physical characteristics. The validation of each regression was done, thanks to the Fisher test (reliability level in Fisher's table used is 0.95). Moreover, in order to know if each factor is significantly separate in the correlation, a student test " $t$ " was carried out. As for the Fisher test, the risk was fixed at 5\%, which means a probability of 0.975 (because this is a bilateral test, [8]).

\subsubsection{Characterisation of the final model}

Several models were obtained and the best significant correlation was obtained for the following equation composed of these three characteristics: $P_{f, I}$ (elastic parameter in fracture toughness), Ec (modulus of elasticity in compression), and SG (specific gravity):

$$
\begin{gathered}
\mathrm{F}_{\mathrm{c}}=\left(0.00139 \times \mathrm{P}_{\mathrm{f}, \mathrm{I}}\right)+\left(0.0031 \times \frac{E c}{S G}\right) \\
\mathrm{R}^{2}=0.80 .
\end{gathered}
$$

This model allowed an improvement of the coefficient of determination and a reduction of $60 \%$ of errors sum of squares (SCE, Tab. VII of the variance analysis). However, to precisely compare the coefficient of determination from simple 
Table VII. Variance analysis of the first model including interactions between factors: elasticity modulus in compression " $\mathrm{E}_{\mathrm{c}}$ ", specific gravity "SG", and Monnin hardness "N".

\begin{tabular}{lcccc}
\hline & Degrees of freedom & Sum of squares & Mean square & F (Fisher) \\
\hline Regression & 2 & 786.37 & 393.19 & 24.07 \\
Error & 12 & 195.99 & 16.33 \\
Total & 14 & 982.36 & \\
\hline
\end{tabular}

and multiple correlations, a new coefficient must be calculated; partial coefficient of determination: $\mathrm{R}^{2}$ [43]:

$$
\mathrm{R}^{\prime 2}=1-\left[\frac{n-1}{n-p-1} \times\left(1-\mathrm{R}^{2}\right)\right] .
$$

It is thus possible to compare results obtained with only specific gravity $\left(\mathrm{R}^{\prime 2}=0.50\right)$, and results obtained with this model $\left(\mathrm{R}^{\prime 2}=0.77\right)$. Then, this formulation allows an improvement of $27 \%$ of the percentage of cutting forces variation explained.

In this model, the factor " $\mathrm{E}_{\mathrm{c}} / \mathrm{SG}$ " characterises the specific compression modulus, and in this way, the cellular-wall mechanical strength, while specific gravity arises only like corrective parameters. Nevertheless, specific gravity influence is included into the tenacity parameter " $\mathrm{P}_{\mathrm{f}, \mathrm{I}}$ " (coefficient of determination of 0.86 between these two factors).

The second factor of the equation is the modulus of tenacity. As described previously, it presents good simple correlation with cutting forces, and translates wood cracking behind the cutting edge. It is something very important during machining and chip formation.

During these tests, it appeared that elastics parameters were the best factors. Two reasons were given in Section 3.2.1 (mechanical and machining point of view); in addition, there are good correlations between failure strains and modulus of elasticity (coefficient of determination close to 0.90).

Then, this kind of model, with factors interactions, seems to be able to explain wood species behaviour and solicitations involved during machining.

\subsubsection{Comparison with different methods}

Today, in France, one of the calculating methods frequently used to estimate quick cutting forces in routing, milling or dressing, use the formula:

$$
\mathrm{F}_{\mathrm{c}}=\mathrm{F}_{1} \times \mathrm{b} \times \mathrm{K}_{\mathrm{e}} \times \mathrm{K}_{\mathrm{h}}
$$

where $F_{1}$ and $b$ are factors depending on cutting parameters; $\mathrm{K}_{\mathrm{e}}$ is the species coefficient (Tab. VIII), and $\mathrm{K}_{\mathrm{h}}$ is the moisture content coefficient [Kivimaa].

This method presents difficulties in precisely estimating cutting forces involved during machining, particularly with difficulties in taking the influence of wood species into account accurately (with the specific gravity factor "Ke"). To solve this problem, a new calculation method was studied with results found there. In fact, a new factor was introduced for the estimation of wood species influence: Km (material coefficient), described as:

$$
\mathrm{K}_{\mathrm{m}}=\left(5.73 \times 10^{-5} \times \frac{E c}{S G}\right)+\left(2.57 \times 10^{-5} \times \mathrm{P}_{\mathrm{f}, \mathrm{I}}\right) .
$$

Table VIII. Determination of the coefficient " $\mathrm{K}_{\mathrm{e}}$ " in the calculation of cutting forces involved during machining; formula (16).

\begin{tabular}{lc}
\hline Wood species & "Ke" coefficient \\
\hline Balsa & 0.5 \\
Polplar & 0.7 \\
Silver fir & 0.8 \\
Beech & 1.0 \\
Niangon & 1.2 \\
Sipo & 1.3 \\
Oak & 1.4 \\
Méranti & 1.5 \\
Azobe & 2.1 \\
Plywood & 1.3 \\
Wood particle board & 1.2 \\
Fiber building board & 2.5 \\
\hline
\end{tabular}

This coefficient "Km" takes the place of the coefficient "Ke" in the formula (16), and the new equation becomes:

$$
\mathrm{F}_{\mathrm{c}}=\mathrm{F} 1 \times \mathrm{b} \times \mathrm{Km} \times \mathrm{Kh} .
$$

In order to estimate the importance of this new formula, it is interesting to compare different calculation methods to estimate cutting forces. As illustrated in Table IX, best results are obtained for new formulation [18] with a gap of only $8.7 \%$ with the reality $(61.6 \%$ with the formula [16] and $13.8 \%$ in the case with only the specific gravity).

Moreover, verification tests were done on other tropical wood species: movingui "Distemonanthus benthamianus Baill.”, and similar results were obtained. In fact, after several other tests, it appeared that this formula seems to be very efficient for all hardwoods (tropical and native), and a little less efficient for softwoods [13].

Figures 11, 12 and 13 showed the improvement of accuracy with the new formula (18), with a better correlation between cutting forces calculated and cutting forces measured. In fact, there is a wage of $25 \%$ of the percentage of cutting forces explained, thanks to wood mechanical characteristics.

\section{CONCLUSION}

The aim of this study was to improve the cutting forces prediction in milling process introducing chosen mechanical and physical parameters in the model.

It was observed that specific gravity was not able to explain, accurately and alone, the relation between wood species and cutting forces involved during machining. In fact, it appeared that best results were obtained for a combination of specific 
Table IX. Comparison of different methods to calculate cutting forces: measure on routing ( $F_{\text {measured }}$ ), measure with formulations [16], [18] and only with the specific gravity $\left(\mathrm{F}_{[16]}, \mathrm{F}_{[18]}\right.$ and $\left.\mathrm{F}_{(\mathrm{ID})}\right)$. Gaps between different methods.

\begin{tabular}{|c|c|c|c|c|c|c|c|}
\hline & $\mathrm{F}_{\text {measured }}$ & $\mathrm{F}_{[16]}$ & $\operatorname{Gap}_{(F[16] / F m e s)}$ & $\mathrm{F}_{(\mathrm{ID})}$ & Gap $_{\text {(FID/Fmes) }}$ & $\mathrm{F}_{[18]}$ & $\operatorname{Gap}_{(F[18] / F m e s)}$ \\
\hline Fromager & 21.14 & 27.33 & 29 & 26.69 & 26 & 21.46 & 2 \\
\hline Ayous & 30.52 & 38.26 & 25 & 29.77 & 2 & 25.74 & 16 \\
\hline Virola & 36.70 & 43.72 & 19 & 32.62 & 11 & 34.37 & 6 \\
\hline Niangon & 46.60 & 65.68 & 41 & 34.06 & 27 & 43.50 & 7 \\
\hline Grignon franc & 28.93 & 38.26 & 32 & 34.48 & 19 & 31.83 & 10 \\
\hline Dodomissinga & 41.65 & 43.72 & 5 & 34.87 & 16 & 38.73 & 7 \\
\hline Frake & 34.59 & 54.65 & 58 & 36.39 & 5 & 39.55 & 14 \\
\hline Beech & 33.19 & 54.65 & 65 & 36.92 & 11 & 34.53 & 4 \\
\hline Bagasse & 36.76 & 76.51 & 108 & 40.13 & 9 & 41.41 & 13 \\
\hline Eucalyptus & 46.31 & 76.51 & 65 & 40.58 & 12 & 39.70 & 14 \\
\hline Moabi & 35.09 & 76.51 & 118 & 40.82 & 16 & 37.05 & 6 \\
\hline Wacapou & 34.06 & 71.05 & 109 & 41.96 & 23 & 40.38 & 19 \\
\hline Ipé & 44.92 & 81.98 & 83 & 44.62 & 1 & 44.27 & 1 \\
\hline \multirow[t]{2}{*}{ Boco } & 55.22 & 114.77 & 108 & 51.77 & 6 & 52.97 & 4 \\
\hline & $37.55 \mathrm{~N}$ & $60.45 \mathrm{~N}$ & $61.59 \%$ & $37.13 \mathrm{~N}$ & $13.76 \%$ & $37.12 \mathrm{~N}$ & $8.66 \%$ \\
\hline
\end{tabular}

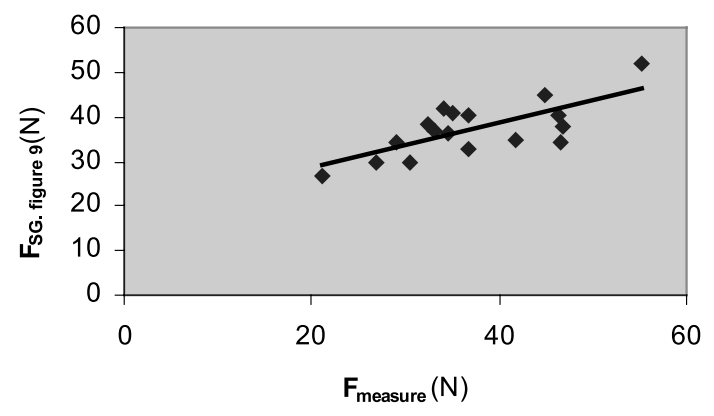

Figure 11. Relationship between cutting forces measure and cutting forces estimate with the formula presented on Figure 9: $\mathrm{F}_{\text {figure } 9}=$ $\left(0.508 \times \mathrm{F}_{\text {measured }}\right)+18.255 ; \mathrm{R}^{2}=0.52$.

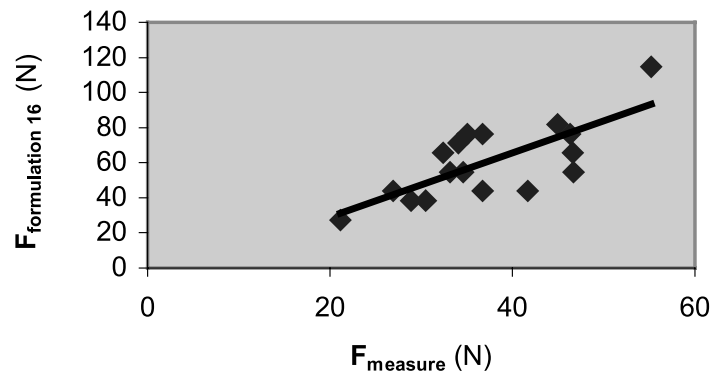

Figure 12. Relationship between cutting forces measure and cutting forces estimate with the formula (17): $\mathrm{F}_{\text {formule } 16}=\left(1.824 \times \mathrm{F}_{\text {measured }}\right)-$ $7.339 ; \mathrm{R}^{2}=0.54$.

gravity with some mechanical parameters. Something surprising is the importance of elastic parameters and the bad correlations obtained with energy parameters. This phenomenon was explained, by the way, to measure cutting forces and mechanical characteristics (difficulty in measuring mechanical characteristics locally, etc.). Moreover, among physical parameters, only specific gravity seems to be interesting to use.

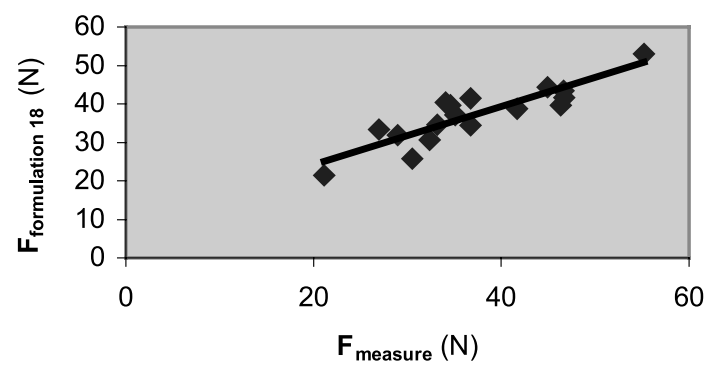

Figure 13. Relationship between cutting forces measure and cutting forces estimate with the formula (19): $F_{\text {formule } 18}=\left(0.755 \times F_{\text {measured }}\right)+$ $9.05 ; \mathrm{R}^{2}=0.78$

However, the last formula (18) showed that internal structural characteristics of each species, and mechanical properties more precisely, were able to lead to knowledge on wood behaviour during machining. And if correlation is not perfect today, it is better; and the use of static mechanical tests is maybe one reason for the imperfection of this new formula. Different results and interpretations will be presented more accurately in the thesis of Eyma [13]. In addition to this work on cutting forces, a similar analysis was done on surface roughness. Moreover, something very interesting is that mechanical properties measured in this work are very close to results found in the Cirad forest data base. So, it is possible to extrapolate these results to the whole of wood species of the Cirad forest.

To conclude, it appeared that the study of physical and mechanical characteristics is a first means to take the wood species factor into consideration correctly, without having to undergo a microscopic analysis. The introduction of this new material coefficient "Km", and the creation of a new formula (18), allowed an improvement of cutting forces evaluation, and a better knowledge of wood behaviour during machining. However, the correlation is still not perfect, and can still be improved, maybe by new physical or mechanical tests ...? or, maybe by the introduction of friction coefficient, ...? All these tests should be done in the future. 
Acknowledgements: We would like to thank the Cirad forest for funding experimental tropical wood, and all the staff of INRA Champenoux center - for their help in the achievement and interpretation of specific gravity results.

\section{REFERENCES}

[1] AFNOR, French standard NF B 51006, approved in February 1942 No. 85364, 1985.

[2] AFNOR, French standard NF B 51007, approved in February 1942, No. $85365,1985$.

[3] AFNOR, French standard NF B 51011, approved in February 1942, No. 80095, 1980.

[4] AFNOR, French standard NF B 51013, approved in February 1942, No. 74789, 1974.

[5] Aguilera A., Optimisation des conditions de coupe pour l'usinage du bois, Thèse de l'Univ. Henri Poincaré de Nancy I, 2000.

[6] Beauchêne J., Évolution du comportement mécanique du bois vert avec la température - application à l'étude du déroulage et du tranchage de quelques bois Guyanais, Thèse présentée à l'ENGREF, 1996.

[7] Chardin A., Utilisation du pendule dynamométrique dans les recherches sur le sciage des bois, Rev. Bois For. Trop. 58, 1958

[8] Cisia-Ceresta, Aide-mémoire statistique, ISBN 2-906711-35-7, 1995.

[9] CTBA, État de l'art et évolutions des performances des machines d'usinage du bois travaillant par enlèvement de copeau, 1991.

[10] Duchanois G., mesure de la ténacité et étude du comportement mécanique des joints bois-colle, Thèse de l'INPL, 1984.

[11] Eyma F., Influence des caractéristiques physiques et mécaniques du bois sur l'usinage, Rapport de DEA sciences du bois, Univ. Nancy I, 1999.

[12] Eyma F., Méausoone P.J., Martin P., Influence of the transitional zone of wood species on cutting forces in the router cutting process (90-0), Holz Roh-Werkst. 59 (2001) 489-490.

[13] Eyma F., Caractérisation des efforts de coupe de différentes essences de bois à l'aide de leurs paramètres mécaniques, thèse de l'Université Henri Poincaré Nancy I, 2002.

[14] Fischer R., Wood cutting simulation - A program to experiment without a machine, Proc. of the 14th IWMS, ISBN 2-87614-362-3, 1999 , pp. 553-562.

[15] Franz N.C., An analysis of the wood-cutting process, Univ. of Michigan Press, Ann. Arbor., Mich., 1958.

[16] Gonçalves M.T.T., Rodrigues R., Takahashi J.S.I., An experimental analysis of the influences of machining conditions on the parallel cutting force in orthogonal cutting for ten Brazilian wood species, Proc. of the 13th IWMS, 1997, pp. 481-487.

[17] Guitard D., Mécanique du matériau bois et composites, Cépaduès éditions, ISBN 2.85428.152.7, 1987.

[18] Gustafsson P.J., Larsen H.J., Fracture energy of wood in tension perpendicular to the grain - results from a join test project, Proc. of CIB-W18A meeting in Lisbon, 1990.

[19] Huang Y-S., Hayashi D., Basic analysis of mechanism in woodcutting, Stress analysis in orthogonal Cutting parallel to grain, Mok. Gak. 119 (1973) 7-12.

[20] Kivimaa E., Cutting force in wood working, Helsinki, 1950.
[21] Klamecki B.E., Friction mechanisms in wood cutting, Wood Sci. Technol. 10 (1976) 209-214.

[22] Koch P., Wood machining process, Cambridge, Ronald press, 1964.

[23] Kollmann \& Coté, Principles of wood science and technology, Vol. I, Solid wood, ISBN 3-540-04297-0, Springer-Verlag, 1984.

[24] Kretschmann D.E., Green D.W., Modeling moisture contentmechanical property relionship for clear southern pine, Wood Fiber Sci. 28 (1995) 320-327.

[25] Larricq P., Une méthode d'estimation des caractéristiques de rupture différée d'un matériau viscoélastique orthotrope, Application au bois, Thèse de l'univ. de Bordeaux I, 1992.

[26] Martin P., Bois et Productique, Cépaduès éditions, ISBN 2.85428.128.4, 1992.

[27] McKenzie W.M., Fundamental analysis of the wood cutting process, thesis of the dept. of wood tech., School of natural resources, Univ. of Michigan, Ann. Arbor., 1961.

[28] McKenzie W.M., The basic wood cutting process, Proc. of the 2nd IWMS, 1967, 3-8.

[29] McKenzie W.M., Ko P., Cvitkovic R., Ringler M., Towards a model predicting cutting forces and surface quality in routing layered boards, Proc of the 14th IWMS, ISBN 2-87614-362-3, 1999 , pp. 489-497.

[30] Merchant M.E., Mechanics of the metal cutting process (I) - orthogonal cutting and a type II chip, J. Appl. Phys.16 (1945) 267-275.

[31] Mothe F., Duchanois G., Zannier B., Leban J-M., Analyse microdensitométrique appliquée au bois : méthode de traitement des données utilisée à l'Inra-ERQB, Ann. Sci. For. 55 (1998) 301-313.

[32] Murase Y., Coefficient of friction and temperature in the sliding friction between wood and steel, Mok. Gak. 36 (1980) 571-575.

[33] Nicault A., Rathgeber C., Tessier L., Thomas A., Observations sur la mise en place du cerne chez le pin d'Alep (Pinus halepensis Mill.): confrontation entre les mesures de croissance radiale, de densité et les facteurs climatiques, Ann. For. Sci. 58 (2001) 769-784.

[34] Orlenko L., Orlenko E., Making the mathematical model of the wood cutting process, Proc. of the 14th IWMS, 1999, pp. 719-723.

[35] Pluvinage G., La rupture du bois et de ses composites, Cépaduès éditions, ISBN 2.85428.292.2, 1992.

[36] Polge H., Établissement des courbes de variation de la densité du bois par exploration densitométrique de radiographies d'échantillons prélevés à la tarière sur des arbres vivants. Applications dans les domaines technologiques et physiologiques, Ann. Sci. For. 23 (1966) 1-206.

[37] Sajus H.W., Irving E., Coiffet P., Modélisation et identification de la force de frottement, Rev. Autom. Prod. Appl. 16 (1993) 65-79.

[38] Sales C., La scie à ruban - théorie et pratique du sciage des bois en grumes, CTFT départ. du CIRAD, 1990

[39] Schatz T., Zur bestimmung der bruchenergierate GF bei holz, Holz Roh-Werkst. 53 (1995) 171-176.

[40] Stewart H.A, Chip formation when orthogonally cutting wood against the grain, Wood Sci. 3 (1971) 193-203.

[41] Triboulot P., Application de la mécanique de la rupture aux bois massifs considérés comme matériaux de construction, Thèse de l'univ. de Metz, 1981.

[42] Triboulot P., Asano I., Ohta M., Rapport final du séjour effectué par P. Triboulot au laboratoire du bois de Mr le professeur Asano, Mok. Gak. 129 (1983) 11-117.

[43] Wonnacott T.H., Wonnacott R.J., Statistique - économie, gestion, sciences, médecine, ISBN 2-7178-2072-8, 1991. 